УДК 61:374.72

DOI: $10.15330 /$ esu. $1.13-18$
Олена Волярська,

доктор педагогічних наук, доцент, Національний медичний університет імені О.О. Богомольця (м. Київ, Україна)

Olena Voliarska,

Doctor of pedagogical sciences, Associate Professor, Bogomolets National Medical University

(Kyiv, Ukraine)

esvdoc@ukr.net

\section{Ірина Гашенко,}

кандидат педагогічних наук, доцент, Національний медичний університет імені О.О. Богомольця

(м. Київ, Україна)

Iryna Hashenko,

Candidate of pedagogical sciences, Associate

Professor, Bogomolets National Medical University

(Kyiv, Ukraine)

irina.gashenko2017@gmail.com

\section{Людмила Коновалова,}

кандидат педагогічних наук, доцент, Національний медичний університет імені О.О. Богомольця (м. Київ, Україна)

Liudmyla Konovalova,

Candidate of pedagogical sciences, Associate

Professor, Bogomolets National Medical University

(Kyiv, Ukraine)

konovalova.lv@ukr.net

\title{
МЕДИЧНА ОСВІТА В СТРУКТУРІ НЕФОРМАЛЬНОЇ ОСВІТИ ДОРОСЛИХ В УКРАїHI
}

\section{MEDICAL EDUCATION IN THE STRUCTURE OF NON-INFORMAL ADULT EDUCATION IN UKRAINE}

Стаття присвячена аналізу теорії і практики медичної просвіти дорослого населення в умовах неформальної освіти Украйні. Обгрунтовано актуальність проблеми освіти дорослих у сучасних сочіально-економічних вимірах. Проаналізовано пріоритетні напрями функиіонування чентрів освіти дорослих в Україні як закладів неформальної освіти. Наголоиено на пріоритетності розвитку неформальної освіти дорослих в Украйні. Визначено, ио підтрунтя розробки нормативної і науково-методичної складових медичної просвіти дорослих складають комплексна очінка, аналіз тематичного спектру освітніх потреб дорослих в сфері медичини, а також можливостей їх задоволения, оцінка якості, територіальної і фінансової доступності різних типів просвітницьких програм. Акцентовано увагу на необхідності розиирения кола провайдерів медичних послуг з освіти дорослих. Охарактеризовано розвиток освіти дорослих у контексті реалізачії міжнародних програм та виявлено перспективні напрями розвитку медичної освіти в структурі неформальної освіти дорослих в Украӥні.

Ключові слова: доросле населення, медична освіта, освіта дорослих, неформальна освіта доросли, провайдери освітніх послуг.

The article is devoted to the analysis of theory and practice of adult education in Ukraine and the role of medical education and its structure. The author substantiates the urgency of adult education problems under modern socio-economic conditions in Ukraine. 
The aim of the article is to analyze the features of the medical education in the non-formal education institutions and to highlight promising areas of its development in the structure of nonformal adult education in Ukraine.

The analysis of the priority areas for functioning of adult education centers in Ukraine as non-formal education institutions. The priority of informal adult education development has been grounded in Ukraine. It is emphasized that a developmental basis for regulatory and scientificmethodical components of adult non-formal education are comprehensive assessment, analysis of the thematic spectrum of adult learning needs and opportunities for their satisfaction, quality assessment, territorial and financial accessibility of different types of educational programs. Some aspects of adult education centers activity have been shown in the article. The attention is drawn to the necessity of expanding the circle of providers giving adult education services.

The authors gave an example of providing additional services to students of medical education institutions and to some categories of adults in Ukraine which are provided by representatives of medical societies and associations.

The promising areas of the development of medical education in the structure of nonformal adult education can be as follows: implementation of cultural and medical projects , popularization of educational ideas of different categories of adults in the field of health protection, making educational environment for adults in the medical institutions as providers of educational services in local communities. In the future, the authors, analyzing the experience of providers of non-formal adult education, consider the doctors' associations to play the dominant role in the adult education in Ukraine.

Key words: adult population, medical education, lifelong education, adult non-formal education, is providers of educational services.

Постановка проблеми у загальному вигляді та ії зв'язок із важливими науковими чи практичними завданнями. Світовий досвід свідчить, що однією 3 закономірностей оновлення суспільства та продуктивного функціонування ринкової економіки є організація освіти на науковій основі, зростання пріоритету професійної підготовки у системі цінностей суспільства. Функціонування формальної та неформальної освіти дорослих об'єктивно пов'язане 3 самовдосконаленням особистості, яка має певний професійний і життєвий досвід.

3 огляду на демографічну ситуацію в країні, важливим для України є вирішення проблеми залучення людей дорослого віку до освітнього процесу. Це зумовлено зміною форм соціального життя, швидкою застарілістю інформації, труднощами міжгенераційної взаємодії, потребою інтеграції людей поважного віку в сучасне суспільство, що в свою чергу зумовлює неперервність освіти, ії вихід за вікові межі та забезпечує природне входження людей дорослого віку в новий етап життя та адаптацію до нього.

На початку минулого століття у багатьох країнах Європи здійснилося злиття різних медичних організацій у національні лікарські асоціації. В Україні на кінець 2019 р. нараховується 140 медичних асоціацій, громадських об'єднань, соціальних фондів, які здійснюють вагомий внесок у розбудову охорони здоров'я України, збереження i примноження традицій української медичної освіти, багаторічну науково-практичну i просвітницьку діяльність. Представники цих асоціацій проводять пленуми, конференщіі, видають журнали, займаються громадською діяльністю і неформальною медичною освітою населення. У зв'язку з цим, набуває актуальності як неформальна освіта дорослих, так і окреслення неформальної медичної освіти для різних категорій дорослого населення в українських реаліях.

Аналіз останніх досліджень і публікацій, в яких започатковано розв'язання порушеної проблеми. У Меморандумі безперервної освіти Свропейського Союзу 
йдеться про необхідність освітніх систем адаптуватися до нових реалій XXI століття [5]. Однією з таких реалій, на нашу думку, є неформальна освіта дорослих.

Проблемам освіти дорослих в Україні присвячено наукові праці О. Аніщенко, Л. Лук'янової, О. Пехоти, С. Прийми. Як зазначає О. Аніщенко, освіта людей дорослого віку представлена в Україні такими закладами та установами, які займаються різними видами формальної та неформальної освіти та просвіти, а саме: громадянською освітою (громадські організації, жіночі центри та об'єднання, сімейні клуби, об'єднання людей третього віку); професійною освітою (професійні асоціації, курси іноземних мов, комп'ютерні курси); об'єднання за інтересами (гуртки, клуби, центри культури); центри освіти дорослих організовані при державних закладах (філармоніях, бібліотеках, музеях, будинках культури, центрах медичної просвіти) [1]. Проте, таке розмаїття освітньої діяльності для дорослого населення в Україні, на жаль, не може бути схарактеризоване як цілісна освіта для дорослих, закономірно пов'язаних між собою елементів, оскільки всі заклади та установи існують розрізнено та об'єднані лише в рамках проектної діяльності.

Аналіз наукових праць з розвитку вищої медичної освіти в Україні (Л. Клос, I. Круковська, I. Мельник, I. Шапіро, А. Яворська) довів, що українська медична освіта розвивалася як частина світової. Колективом авторів (І. Булах, О. Волосовець, Ю. Вороненко) було проаналізовано систему управління якістю медичної освіти в Україні [3]. У цьому контексті набуває актуальності потреба вивчення досвіду медичної освіти дорослого населення в закладах та організаціях неформальної освіти, які існують в Україні.

Виокремлення невирішених раніше аспектів загальної проблеми, які суголосні із статтею. У працях вітчизняних науковців багато цінного, їхній критичний аналіз сприяє систематизації знань із проблем медичної освіти дорослого населення в Україні. Проте необхідно зазначити, що автори лише частково звертали увагу на проблеми неформальної освіти дорослого населення в сфері охорони здоров'я.

У психологічній і педагогічній літературі нині немає праць, присвячених розгляду специфіки медичної освіти різних категорій дорослого населення в структурі неформальної освіти дорослих в Україні. Як наслідок залишаються недостатньо з'ясованими зміст, форми і методи педагогічного впливу на цей процес. Високо оцінуючи здобутки українських вчених та освітян-практиків, слід зазначити, що у вітчизняній науці відсутні комплексні дослідження, які присвячені організації і впровадженню медичної освіти населення в умовах неформальної освіти дорослих.

Формулювання цілей статті (постановка завдання). Мета статті - проаналізувати особливості медичної освіти населення в закладах неформальної освіти та виокремити перспективні напрями іі розвитку в структурі неформальної освіти дорослих в Україні.

Виклад основного матеріалу дослідження 3 повним обгрунтуванням одержаних наукових результатів. Входження України у Свропейській освітній простір вимагає розбудови багатьох сегментів системи пожиттєвого навчання, яке стимулює модернізацію соціальної, економічної та гуманітарної сфери держави. Освіта впродовж життя має на увазі зростання інвестицій у сферу навчання дорослого населення та охоплює все цілеспрямоване навчання особистості (формальне чи неформальне) з метою вдосконалення навичок і компетенцій. Водночас, неперервна освіта людини не обмежується формальною освітою, потрібно брати до уваги неформальну та інформальну форми освіти дорослих. 
Аналіз наукових джерел і власний педагогічний досвід авторів свідчать про те, що центри освіти дорослих в нашій країні $є$ складниками освітньої діяльності в окремих регіонах. Центри освіти дорослих (ЦОД) є місцями соціальної інтеграції різних груп дорослого населення. Відзначимо, що на початку XXI ст. в Україні центри освіти дорослих функціонували або як самостійні культурно-просвітницькі інституції, або як структурні підрозділи навчальних закладів, установ. Вони є освітніми майданчиками для дорослих з різними особистісними і професійними потребами у навчанні.

Науковцями відділу андрагогіки Інституту педагогічної освіти і освіти дорослих Національної академії педагогічних наук України на основі міждисциплінарного підходу здійснено системний аналіз проблеми проектування документації, організації і функціонування центрів освіти дорослих в Україні. Так, О. Аніщенко зазначає, що центри освіти дорослих є місцями соціальної інтеграції різних категорій дорослого населення. Вони $є$ освітнім простором для дорослих 3 різними особистісними i професійними потребами. Діяльність центрів освіти дорослих як громадських організацій спрямована на здійснення широкого спектру освітніх послуг, які відповідають запитам і потребам різних категорій дорослого населення [1].

Позитивно оцінюючи досвід країн Європи в розбудові мережі закладів неформальної освіти дорослих, зазначимо, що українським реаліям (у зв'язку з наявною нормативно-правовою базою) більш відповідає така модель неформальної освіти дорослих як центри освіти дорослих, які створені на базі громадських організацій. Діяльність центрів освіти дорослих як громадських організацій спрямована на здійснення широкого спектру освітніх послуг, які відповідають запитам і потребам різних категорій дорослого населення. Центри освіти дорослих сприятимуть проектуванню та реалізації андрагогічно орієнтованої освітньої діяльності.

Українськими науковцями О. Волярською, О. Пастушок встановлено, що до пріоритетних напрямів діяльності центрів освіти дорослих у громаді належать: організаційно-технологічне забезпечення супроводу освіти й навчання різних категорій дорослого населення; розроблення навчальних програм для освіти різних категорій дорослих у контексті неперервної освіти дорослих; організація і проведення заходів щодо моніторингу потреб дорослих у освітніх послугах; реалізація спільних соціально-спрямованих проектів з організації медичної просвіти різних груп дорослого населення [2].

На наше переконання, серед завдань діяльності центрів освіти дорослих в громаді слід виокремити: 1) аналіз сучасних вітчизняних і зарубіжних освітніх тенденцій; 2) вивчення культурно-освітніх потреб різних категорій дорослого населення для подальшої розробки відповідного організаційно-навчального забезпечення освітнього процесу в умовах неформальної освіти; 3) впровадження інноваційних навчальних технологій, спрямованих на підвищення якості та ефективності навчання дорослих; 4) висвітлення результатів соціалізації різних груп дорослого населення шляхом організації та проведення в громаді семінарів, форумів, круглих столів тощо; 5) взаємодія 3 регіональними закладами сфери охорони здоров'я в України, територіальними центрами соціального обслуговування громадян, підприємствами, установами, організаціями щодо організації додаткової медичної освіти для різних категорій дорослого населення.

Зауважимо, що сьогодні в Україні функціонус доволі розвинута мережа закладів вищої медичної освіти різного рівня акредитації, яка готує спеціалістів для потреб вітчизняної охорони здоров'я, а також фахівців для інших країн світу. Медична освіта забезпечується мережею медичних, фармацевтичних і стоматологічних коледжів, інститутів, академій та університетів, у яких здійснюється середньо-спеціальна та вища фахова підготовка, перекваліфікація та вдосконалення 
майстерності, а також післядипломна освіта лікарів та медичного персоналу різного рівня. Проте, неформальна медична освіта дорослих представлена окремими лікарськими асоціаціями, товариствами, громадськими організаціями і спілками.

Наголосимо, що теоретичне обгрунтування організації i функціонування медичної освіти дорослого населення в умовах неформальної освіти дорослих, дозволяє без наявності достатнього нормативного забезпечення у рамках діючого законодавства створювати в Україні громадські організації з освіти впродовж життя та спільно із органами місцевого самоврядування задовольняти освітні потреби різних груп дорослого населення.

Зазначимо, що активними представниками в сфері неформальної медичної освіти в Україні є Асоціація пластичних хірургів України, Асоціація інфекціоністів України, Всеукраїнське лікарське товариство, громадські організації “Асоціація медиків Революції Гідності”, “Асоціація з медичної та психологічної реабілітації” “Асоціація нейрохірургів”, “Асоціація фахівців з формування здорового способу життя”, Київське відділення громадської організації “Українська асоціація сприяння охороні здоров'я населення", громадська організація “Всеукраїнська фармацевтична палата”, громадська спілка “Українське агентство 3 оцінки технологій охорони здоров'я", Асоціація організаторів охорони здоров'я Дніпропетровської області, Асоціація стоматологів України, Національна лікарська рада України, Українська асоціація сімейної медицини, громадська спілка “Об’єднання організацій медичних працівників України”, всеукраїнська громадська організація "Спілка громадських організацій "Народна рада" тощо. Діяльність цих лікарських асоціацій, громадських організацій та спілок спрямована на проведення прикладних досліджень 3 проблем медичної просвіти різних категорій дорослих, а також на надання різноманітних додаткових медичних та освітніх послуг як самим медичним працівникам, лікарям, так і всім бажаючим.

Як приклад наведемо налагодження співпраці 3 надання дорослим додаткових освітніх послуг у сфері охорони здоров'я між медико-психологічним факультетом Національного медичного університету імені О.О. Богомольця та громадською організацією “Асоціація з медичної та психологічної реабілітації. Так, тільки у жовтні 2019 р. для студентів університету і всіх бажаючих, хто цікавиться сучасними медичними заходами, було запропоновано майстер-класи і тренінги у рамках III Міжнародної науково-практичної конференції “Психоонкологія-2019" і II Міжнародної науковопрактичної конференції “2019-Ukrainian Mental Health Conference” та модуль навчання “Метод біосугестивної терапії” для корекції і лікування психосоматичних розладів.

Варто акщентувати увагу на тому, що Кабінет Міністрів України у березні 2018 р. затвердив "Положення про систему безперервного професійного розвитку фахівців у сфері охорони здоров'я". У цьому документі окреслено основні організаційні засади безперервного процесу навчання та вдосконалення професійних компетентностей фахівців після здобуття ними вищої освіти у сфері охорони здоров'я та післядипломної освіти в інтернатурі. Відзначимо, що безперервний професійний розвиток включає участь медичних працівників у процесі формальної, неформальної та інформальної освіти у сфері охорони здоров'я. Так, у Положенні визначено, що “неформальна освіта у сфері охорони здоров'я (далі - неформальна освіта) - діяльність 3 підвищення власних знань та вмінь, яка провадиться за освітніми програмами та не передбачає присудження визнаних державою освітніх кваліфікацій за рівнями освіти, але може завершуватися присвоєнням професійних та/або присудженням часткових освітніх кваліфікацій” [4]. Вищезазначене свідчить про те, що на законодавчому рівні в Україні відбувається розширення кола провайдерів освітніх послуг 3 неформальної медичної освіти дорослого населення. 
Серед перспективних напрямів розвитку медичної освіти в структурі неформальної освіти дорослих, на нашу думку, варто виокремити такі: упровадження культурно-освітніх проектів медичної спрямованості, популяризація ідей просвіти різних категорій дорослого населення в сфері охорони здоров'я, створення навчального середовища для зацікавлених категорій дорослих у медичних закладах, як провайдерів освітніх послуг у місцевих громадах.

Висновки представленого у статті дослідження і перспективи подалыших наукових розвідок із зазначеного напряму. Таким чином, аналіз української медичної освіти засвідчив, шо лікарські асоціації, громадські організації і спілки як заклади неформальної освіти ефективно функціонують, якщо їхня діяльність полягає в розробці та реалізації індивідуальних програм освіти за потребами різних груп населення, взаємодії з ринком праці, замовниками та споживачами лікарських кадрів. Зауважимо, що стратегічною метою медичної освіти дорослих вструктурі неформальної освіти в Україні $\epsilon$ iï професійна спрямованість і задоволення освітніх потреб різних категорій дорослого населення в сфері охорони здоров'я. Таке розуміння, на наш погляд, сприяє адаптованості і соціальній зрілості дорослої людини, змінює іiі особистісну та соціальну поведінку і надає можливість вести здоровий спосіб життя.

На наше переконання, неформальна медична освіта дорослого населення в Україні повинна бути інтегрована в систему освіти дорослих. Важливу роль у цьому процесі відведено органам державної влади (перш за все профільним, як-то Міністерство освіти і науки, Міністерство охорони здоров'я, Міністерство соціальної політики, Міністерство культури), науковим установам, закладам вищої освіти, громадським організаціям тощо.

У подальшій перспективі вважаємо за необхідне проаналізувати досвід провайдерів освіти дорослих в сфері охорони здоров'я, серед яких домінуючу роль грають українські лікарські асоціації і товариства.

\section{Література}

1. Аніщенко О. В. Моделі центрів освіти дорослих в Україні // Освіта дорослих: теорія, досвід, перспективи. Київ; Ніжин: ПП Лисенко М.М., 2018. - Вип. 1 (14). - С. 22-35.

2. Волярська О. С., Пастушок О. І. Освіта дорослих у Польщі: теорія і практика (друга половина XX - початок XXI століття): монографія. Никополь: ТОВ "Принтхаус "Римм", 2018. - 172 с.

3. Система управління якістю медичної освіти в Україні: монографія / I.С. Булах, О.П. Волосовець, Ю.В. Вороненко та ін. -Д.: “АРТ-ПРЕС”, 2003. - 212 с.

4. Постанова Кабінету Міністрів України "Положення про систему безперервного професійного розвитку фахівців у сфері охорони здоров'я" - Режим доступу: https://zakon.rada.gov.ua/laws/ show $/ 302-2018-\% \mathrm{D} 0 \% \mathrm{BF}$

5. A Memorandum on Lifelong Learning / Commission of the European Communities. - Brussels, 30.10.2000- URL: http://arhiv.acs.si/dokumenti/

\section{Reference}

1. Anishchenko O. V. Modeli tsentriv osvity doroslykh v Ukraini // Osvita doroslykh: teoriia, dosvid, perspektyvy. Kyiv; Nizhyn: PP Lysenko M.M., 2018. - Vyp. 1 (14). - S. 22-35.

2. Voliarska O. S., Pastushok O. I. Osvita doroslykh u Polshchi: teoriia i praktyka (druha polovyna XX - pochatok XXI stolittia): monohrafiia. Nykopol: TOV "Pryntkhaus "Rymm", 2018. - $172 \mathrm{~s}$.

3. Systema upravlinnia yakistiu medychnoi osvity v Ukraini: monohrafiia / I.Ie. Bulakh, O.P. Volosovets, Yu.V. Voronenko ta in. -D.: "ART-PRES", 2003. - $212 \mathrm{~s}$.

4. Postanova Kabinetu Ministriv Ukrainy "Polozhennia pro systemu bezperervnoho profesiinoho rozvytku fakhivtsiv u sferi okhorony zdorovia" - Rezhym dostupu: : https://zakon.rada.gov.ua/laws/ show/302-2018-\%D0\%BF

5. A Memorandum on Lifelong Learning / Commission of the European Communities. - Brussels, 30.10.2000- URL: http://arhiv.acs.si/dokumenti/ 